\title{
Journal of Ecological Anthropology
}

Volume 18

Issue 1 Volume 18, Issue 1 (2016)

Article 10

February 2017

\section{Front Matter}

Follow this and additional works at: http://scholarcommons.usf.edu/jea

\section{Recommended Citation}

. "Front Matter." Journal of Ecological Anthropology 18, no. 1 (2016): I-V.

Available at: http://scholarcommons.usf.edu/jea/vol18/iss1/10 


\section{Journal of \\ Ecological Anthropology}

Volume i 8, 2016

Number I 


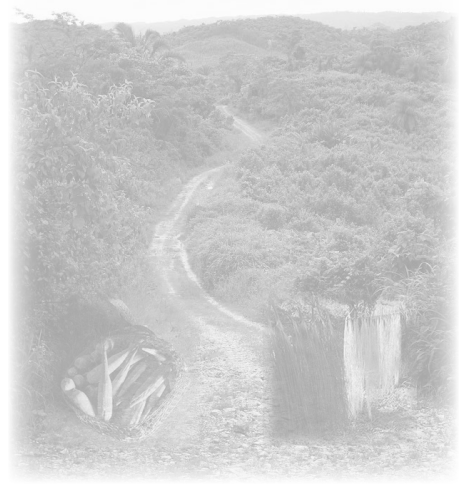

\begin{abstract}
About the Cover
Our cover images come from author Kristina Baines' work with the Mopan Maya community of Santa Cruz, Belize. Baines examines how ecological heritage practices, for example planting corn and collecting wild plants, are linked to how community members define and experience health. The author developed a community-specific measure to explore the links between health and heritage among households with differing levels of engagement with "healthy" activities that are also seen as important in terms of heritage. As environmental and economic changes impact daily lives in Santa Cruz, the roles that specific activities play in how holistic health is defined and maintained becomes increasingly critical to understand.
\end{abstract}

ISSN 1528-6509

All content for Journal of Ecological Anthropology is licensed under a Creative Commons Attribution-NonCommercial 4.0 International License.

(c) (i) (8)

Journal of Ecological Anthropology

Department of Anthropology

University of South Florida

4202 E. Fowler Ave., SOC 107

Tampa, FL 33620

jea.editors@gmail.com

http://scholarcommons.usf.edu/jea/ 


\section{Editors-in-Chief}

Eric C. Jones, University of Texas Health Science Center at Houston

Rebecca K. Zarger, University of South Florida

\section{Production Editor}

Chelsea Johnston, University of South Florida

\section{Book Review Editor}

Carylanna Taylor, Research Consultant

\section{Editorial, Production and Administrative Assistants}

Mary Gerardo, University of Texas Health Science Center at Houston

Joanne Hoffman, Lehigh University

Sara Masoud, University of Texas Health Science Center at Houston

Ann Vitous, University of South Florida

Sarah Bradley, University of South Florida

Claudia Calderon, University of Texas Health Science Center at Houston

Cristina Castillo, University of Texas Health Science Center at Houston

\section{Editorial Board}

David Casagrande, Lehigh University

Charles Peters, University of Georgia

John R. Stepp, University of Florida

\section{Advisory Board}

Eugene N. Anderson, University of California, Riverside

Myrdene Anderson, Purdue University

Fikret Berkes, University of Manitoba, Canada

Brent Berlin, University of Georgia

Timothy Finan, University of Arizona

David Griffith, East Carolina University

Jacquetta Hill, University of Illinois

Alf Hornborg, Lund University

Willett Kempton, University of Delaware

Conrad P. Kottak, University of Michigan

Stephen Kowalewski, University of Georgia

Luisa Maffi, Terralingua

Bonnie J. McCay, Rutgers University

Emilio F. Moran, Indiana University

Victor Toledo, Universidad Nacional Autónomo de Mexico

Patricia K. Townsend, State University of New York, Buffalo

Timothy Wallace, North Carolina State University

Felice S. Wyndham, University of British Columbia

The Journal of Ecological Anthropology is published independently and without profit. The Department of Anthropology at the University of South Florida provides institutional and financial support, and the School of Public Health at the University of Texas Health Science Center at Houston provides financial support. 


\section{Contents}

Editor's Note

\section{Articles}

Migration, Labor Scarcity, and Deforestation in Honduran Cattle Country

David C. Griffith, Raquel Isaula, Pedro Torres, and Manuel Villa Cruz

Learning to Survive Ecological Risks among the Sidama of Southwestern Ethiopia 17

Samuel J. Dira and Barry S. Hewlett

Responding to Modern Flooding: Old English Place-Names as a Repository of Traditional Ecological Knowledge 36

RichARD L.C. JONES

\section{Crib Notes}

The Life and Times of Landfills 61 Joshua O. Reno

\section{Data Notes}

Pastoralists' Perception on the Trend of Various Climatic, Social and Environmental Variables in Baringo County, Kenya 68

Geoffrey L. Lelenguyah, Samuel K. Kabochi, and John C. Biwot

The Environmental Heritage and Wellness Assessment: Applying Quantitative Techniques to Traditional Ecological Knowledge and Wellness Relationships 77 Kristina Baines

Fish Names Variability Traces the Geo-Historical Dynamics of Moroccan Fishermen Communities 86

Hicham Masski and Abdelaziz Ait Hammou

\section{Book Reviews}

Things Fall Apart? The Political Ecology of Forest Governance in Southern Nigeria 97

Culture and Conservation: Beyond Anthropocentrism 


\section{EDitor's Note}

With so many opportunities in so many academic fields to study societal change, we appreciate the attention the authors in this volume of Journal of Ecological Anthropology give to myriad ways that such societal change engages non-human life and matter. In this volume, scholars attend to the creation of new economic relations as people reconfigure their relationship to agriculture (Griffith); how people adapt to a changing climate (Dira and Hewlett; Lelenguyah, Kabochi, and Biwot); how names for things actually contain information about prior ecology and prior human-environment relationships (Jones; Masski and Ait Hammou); how we might rethink the nature of landfills (Reno); how to study wellbeing in relation to environmental knowledge (Baines); and how politics engages resource conservation (book reviews by Kashwan and Poirier).

A long-time scholar of livelihoods, David Griffith has teamed up with Raquel Isaula, Pedro Torres, and Manuel Villa Cruz for the research article "Migration, Labor Scarcity, and Deforestation in Honduran Cattle Country," which covers families who, amidst the societal change of outmigration, find themselves without sufficient labor to continue their way of farming. This is well known throughout the world-particularly resulting from rural-to-urban labor migration — and leads to two main dynamics in northeastern Honduras. First, ranching is less labor intensive and thus replaces much of agricultural activity and, second, some people have left farming for carpentry, which has clear impacts on local forests.

Samuel Dira and Barry Hewlett investigate in their research article how the biophysical environment impinges on Sidama life in Ethiopia, without portraying a lack of human agency. The authors focus on ways in which people teach and learn about ecological change and risk factors that affect their livelihoods. Threats of food shortage and drought are met by teaching and learning the survival skills of saving (taught by parents) and trading (learned from peers), among others. Dira and Hewlett look at both the horizontal and vertical transmission of such ecological knowledge.

There is an extraordinary story bound up in place-names that people assigned hundreds of years ago in England, according to Richard Jones. Even though the knowledge might not be actively known or practiced currently, Jones suggests that some ethnohistorical sleuthing about place-names can discover patterns of how people pass on some forms of ecological knowledge for centuries without even comprehending that names contain information about the biophysical environment. With all the scholarly attention to purposefully maintained indigenous knowledge, this perspective about unconscious knowledge helps us to realize that human-environmental interactions contain embedded information in the form of language that may not be widely known or understood.

Landfills are accumulations of waste in a place, but in his Crib Note Joshua Reno conceptualizes how landfills are also sociotemporal in their manifestations. Any effort to rework waste streams as well as how landfills are created and managed must take into account how complex they are biologically, environmentally, and socially.

Three short pieces that provide insights into the study of ecological knowledge find their home in the Data Notes section. Geoffrey Lelenguyah, Samuel Kabochi, and John Biwot found that pastoralists and agro-pastoralists in Kenya are noticing different kinds of changes in rainfall and its effects. Kristina Baines generated a unique dataset on ways to study health and wellbeing that is intimately linked to environmental heritage in a Mopan Maya community in southern Belize. Baines describes a methodology that would ideally allow others to build upon this effort to understand ecological aspects of a life welllived. Hicham Masski and Abdelaziz Ait Hammou matched 691 fish names to 138 species to give a 
glimpse into ethnic engagement of fisheries across Morocco's long coast over hundreds of years. While their interest is in understanding the kind of linguistic confusion that regulators encounter as they try to standardize nomenclature, this study should also be seen as an important and innovative contribution to the human ecological history of Morocco.

Finally, two book reviews in this issue illustrate the complexities of current understandings of conservation. A book reviewed by Prakash Kashwan focuses on a political ecological assessment of forestry in Nigeria, where local experiences mix with bureaucratic constraints within a colonial land tenure legacy to fashion land use, deforestation, and conservation that are far more complex than conservationists and social justice seekers tend to see. The other book is an edited volume reviewed by Nathan Poirier that advocates finding a common ground between anthropocentric and eco-centered environmental justice when thinking about the goals and means of conservation through a variety of case studies in locations around the globe.
With the need for clear thinking and inquiry into human-environment relations never more important, we encourage scholars in their presentation of their work here and elsewhere to be creative with alternative explanations/hypotheses, as well as creative formats to include visual, spatial, and other non-traditional formats. Special thanks to our hardworking editorial assistants Ann Vitous and Sarah Bradley at the University of South Florida (USF), Sara Masoud, Claudia Calderon, and Mary Gerardo at the University of Texas Health Science Center at Houston, and Cristina Castillo at the University of Texas at El Paso, the Journals selfless and thoughtful reviewers, as well as to the USF ScholarCommons journal production staff, particularly Chelsea Johnston and Alex Onac.
Sincerely,

ERIC C. Jones

Rebecca K. Zarger

Co-Editors 